\title{
BETWEEN THE AGE OF HEROES AND THE PERIOD OF PROFESSIONAL TROOPS. EVIDENCE FROM THE BORDERLAND OF SILESIA, BRANDENBURG, LUSATIA AND POLAND
}

\begin{abstract}
This paper is concerned with the transformations that took place in the late-medieval and early-modern borderland of Silesia, Greater Poland, Brandenburg and Lusatia in the forms of arms and armour used between the end of the $15^{\text {th }}$ - and the beginning of the $16^{\text {th }}$ century. Gothic elements of arms and armour still exist in the iconography of the borderland until the $2^{\text {nd }}$ decade of the $16^{\text {th }}$ century. Fully developed Renaissance arms and armour (Maximilian, fluted, costume) appear in iconography of this region not earlier that 1530 s.
\end{abstract}

Keywords: arms and armour, Gothic, Renaissance, fluted armour, Maximilian armour, costume armour

Received: 06.04.2020 Revised: 11.05.2020 Accepted: 31.05.2020

Citation: Michalak A. 2020. Between the Age of Heroes and the Period of Professional Troops. Evidence from the Borderland of Silesia, Brandenburg, Lusatia and Poland. "Fasciculi Archaeologiae Historicae" 33, 71-87, DOI 10.23858/FAH33.2020.005

The revolutionary changes that took place at the end of the Middle Ages, related to the rapid development of firearms, forced the transformation of military equipment used by "servants of war". The process of "infantry revolution" in Western Europe which is commonly believed to have begun c. 1300 onwards, was related with the emergence of properly trained and organised infantry formations, armed mostly with polearms. ${ }^{1}$ The success of professional infantrymen on the battlefield, not guided by the code of honour, led to the gradual abandonment of chivalric ideals. Heavy-armed cavalry which personified this ethic have not yet left the theatre of war, although the military role of mounted knights on the battlefield was continuously diminishing. In the $2^{\text {nd }}$ half of the $16^{\text {th }}$ centu$\mathrm{ry}^{2}$ the arms race between arms and armour makers ended in the defeat of protective armaments and caused a slow departure from the use of full suits of plate armour. ${ }^{3}$

\footnotetext{
*Archaeological Museum of the Middle Odra River Area in Świdnica near Zielona Góra; (D https://orcid.org/0000-0002-84068787; a.michalak@muzeum-swidnica.org

${ }^{1}$ DeVries 1996, 191-192.

${ }^{2}$ Ayton and Price 1995, 2.

${ }^{3}$ Full suits of armour were rarely worn from the $2^{\text {nd }}$ half of the $16^{\text {th }}$ century onwards, however heavy three-quarter cavalry armour remained in common use until the mid- $17^{\text {th }}$ century, Oakeshott 1980, 209.
}

Knightly ideals and tradition, despite the fact that they were not continued in war conditions, found their manifestation in tournaments. Plate armour, the symbol of a knight, came to be worn less and less in battle, but found a new use at parades, tournaments and other court ceremonies. All these new trends had profound impact on the forms of arms and armour used at the beginning of the $16^{\text {th }}$ century. The Gothic slender lines representative for the German-style armour defining the male figure was replaced; instead of the slenderness and sharpness, the width and roundness of the form and the softening of the contours appeared. The balance of vertical and horizontal tensions once again brought the armour to the shapes conforming to the human being, which fully refer to the humanism belief of the beauty of human body structure. ${ }^{4}$ Constructed armours with perfectly articulated structures pulsed with the Renaissance fascination with the mechanics of nature.

The conflicts that swept across Europe at the end of the $15^{\text {th }}$ - and the beginning of the $16^{\text {th }}$ century related to the rivalry between the Habsburgs and the House of Valois, as well as the rapid increase in the power

\footnotetext{
${ }^{4}$ Żygulski Jr. 1975, 152.
} 


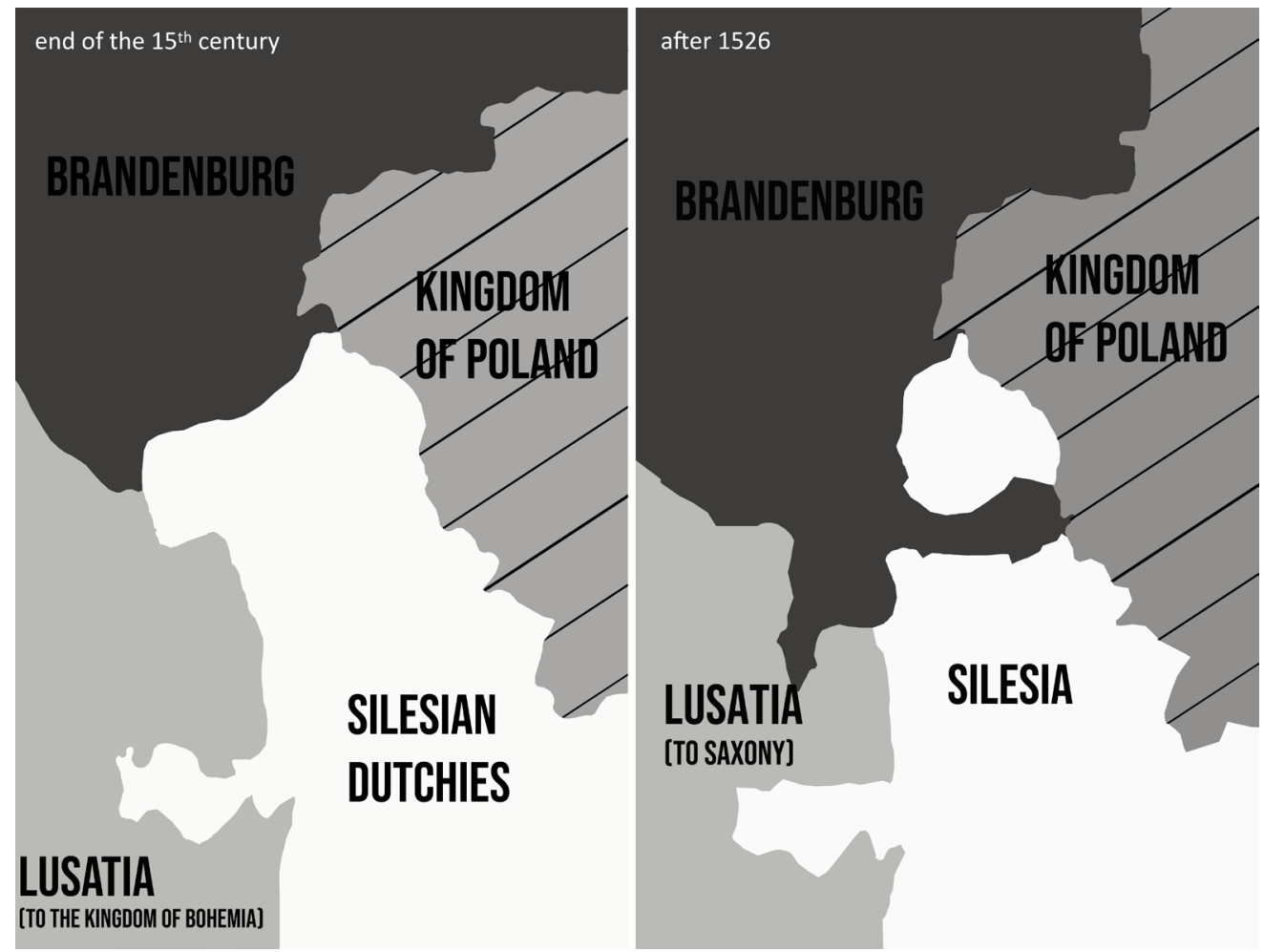

Fig. 1. Territorial changes in the borderland of Silesia, Brandenburg, Greater Poland and Lusatia at the end of the Middle Ages and dawn of the Modern Period. Elaborated by A. Michalak.
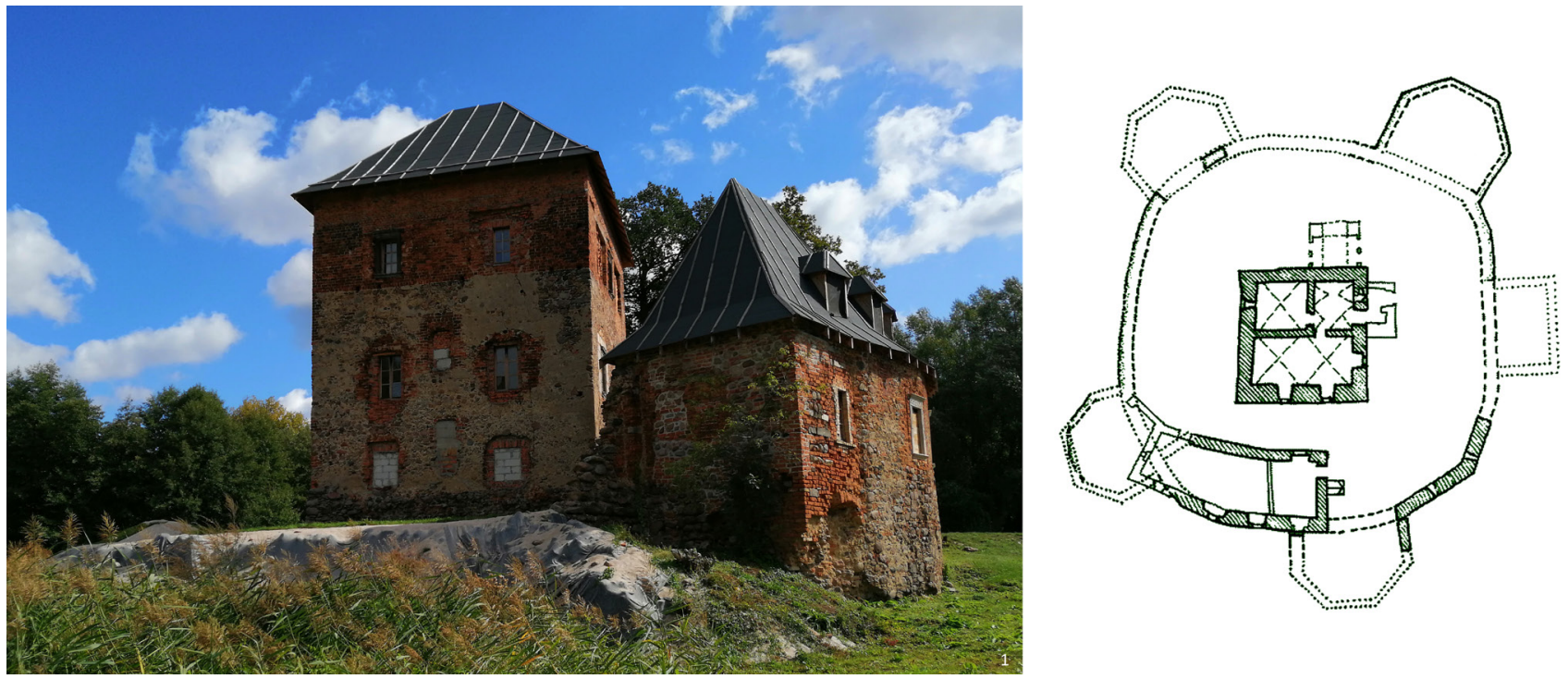

Fig. 2. Witków (Wittgendorf): 1 - the tower house erected c. 1400, by the members of Warnsdorf family. Photo A. Michalak; 2 - with bastions built in the $1^{\text {st }}$ half of the $16^{\text {th }}$ century. After Kowalski 2010.

of Ottoman Turkey also affected the situation in Central Europe. In the Late Middle Ages the territory of the mid-Odra Region was the arena of struggle between the Silesian Duchies, the Kingdom of Poland, Brandenburg and the Kingdom of Bohemia. The territorial status quo established during the $15^{\text {th }}$ century, was significantly changed during the War of the Głogów Succession (1476-1482), when the crucial Ziemia Krośnieńska (Germ. Crossen/Crosno land) had been gained by Margrave Albrecht Achilles of Brandenburg. ${ }^{5}$ During the early $16^{\text {th }}$ century Silesia was controlled by the Kingdom of Bohemia, and after the death of the king of Bohemia, Louis II of Hungary, in the battle of Mohacs (1526), it was incorporated into the Habsburg Monarchy. ${ }^{6}$ This event stabilised

\footnotetext{
${ }^{5}$ Szczegóła 1968, 105.

${ }^{6}$ Goliński 2006, 189-190.
} 

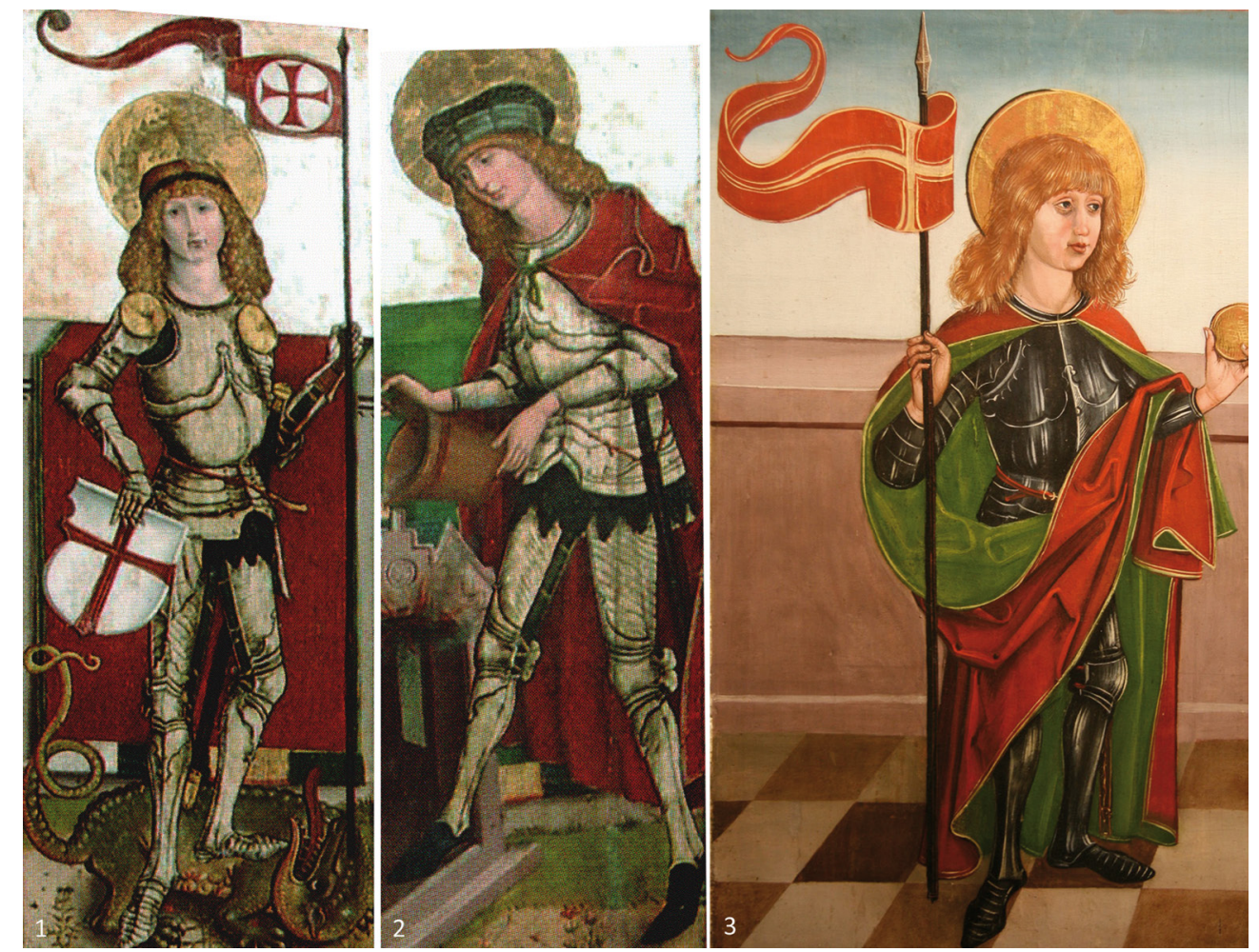

Fig. 3. Medieval reminiscences from the early $16^{\text {th }}$ century. Depictions of Gothic armour from altarpieces made by the Master of Polyptych from Gościszowice: 1-2 - Tryptych of the Mother of God, Convent of the Penitential Sisters of Mary Magdalene in Lubań, now in the Archdiocesan Museum in Wrocław, $2^{\text {nd }}$ decade of the $16^{\text {th }}$ century; 3 - altar from St. Joseph's church in Bloischdorf, c. 1510-1515. After Michalak 2019.

the political situation and borders in the borderland for over 200 years $^{7}$ (Fig. 1).

Significant changes occurred at that time in the field of military and residential architecture. It was associated with the spread of bastion fortifications (trace italienne), connected with the increase of importance of artillery, as well as the adoption of new stylistic and cultural trends. These transformations are visible in many castles in this region, rebuilt in the $1^{\text {st }}$ half of the $16^{\text {th }}$ century. For instance, in this period polygonal bastions were added to the tower house in Witków (Germ. Wittgendorf); (Fig. 2). ${ }^{8}$ To some extant castle inventories of weapon supplies stand as testimony to these changes. For example, in the castle in Krosno, during the inventory made in 1505 , when the castle was taken over by Jerzy Schlabendorff, there were 2 Houfnice, 1 Culverin (schlangen), 6 hackbutts, 7 gunpowder kegs, half keg of lead/iron bullets (geloten), but also 240 projectile shafts and bolt heads for crossbow. ${ }^{9}$

Service for the sovereign, Ritterdienst was still the basic duty of the noble owners of castle estates. To increase the real combat qualities of the noble army in peacetime military drills were organised. In the Dutchy

\footnotetext{
${ }^{7}$ Kuczer 2007, 34

${ }^{8}$ Kowalski 2010, 404-405; Michalak 2010, 168.

${ }^{9}$ CDB 1858, 127-129, 201-202.
}

of Głogów (Germ. Glogau), according to the privileges of Ferdinand I, these were to take place at least once a year. From year to year, fewer and fewer members of the nobility took part in them. ${ }^{10}$ In real terms, tournaments, embodying knighthood ${ }^{11}$ so important for nobility, had even less significance. ${ }^{12}$ In this part of Europe, the most important tourneys were held at the court of electors of Saxony in Dresden, and most likely also important trends in the field of arms and armour spread from there. ${ }^{13}$

Development and improvements in different regions were introduced progressively. Essential questions that need to be answered in this paper are: when did gothic-style armour fade away from the iconography of the area in question? How long did offensive weapons of medieval origin exist during the Modern Period? Exactly when did avant-garde innovations appear in the iconography of this region? Is iconography, in light of archaeological evidence, a reliable source? Due to the almost complete lack of original artefacts from museum collections that could be undeniably considered as related to the region in question, this paper

\footnotetext{
${ }^{10}$ Kuczer 2007, 245.

${ }^{11}$ Breiding 2012, 55.

12 Brzustowicz 1997, 34-38.

${ }^{13}$ Bäumel 1992, 350-351.
} 


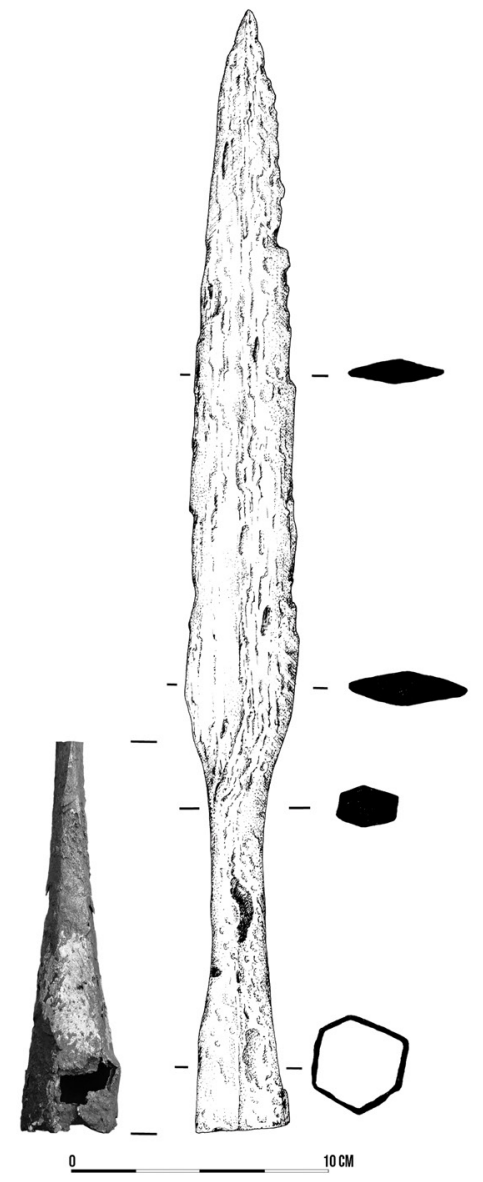

Fig. 4. Boar- or bearspear head from the collection of the Archaeological Museum of the Mid-Odra River Region in Zielona Góra. Drawn and photo A. Michalak and D. Krzyżyńska.

will be based mainly on archaeological examples and iconographic evidence, obviously being aware of the limitations that the latter carry (e.g. the objection positing artistic stylization by the artists). Noticeably fewer sources are known from the northern part of the region. ${ }^{14}$ The collected evidence may indicate some lags in the introduction of arms and armour innovations into area in question.

Changes took place gradually. There is no doubt that late-medieval armament existed far beyond the conventionally agreed end date of the Middle Ages in 1500. The occurrence of Gothic armour in iconography until the second decade of the $16^{\text {th }}$ century, as in the case of panel painting from the workshop of the Master of the Polyptych from Gościeszowice (Germ. Giessmansdorf), may well confirm this observation ${ }^{15}$ (Fig. 3).

In the field of offensive weapons, the period of using forms of medieval origin is longer than has been assumed so far. For example, one should mention twohand swords enabling slashing blows, which in the light

${ }^{14}$ Reißman 1937, 126, 129-130, 150; Tureczek 2009, 113-114, 117, Figs. 7-9; Zdrenka 2015, 339, Fig. 39

15 Patała 2018, 250-277; Michalak 2019, 47-63. of iconographic sources were also used until the end of the second decade of the $16^{\text {th }}$ century. ${ }^{16}$ They usually had pear-shaped pommels. This specific form, with grooved surfaces, enjoyed great popularity in this area at the end of the late Middle Ages and at the beginning of the Modern Period. According to A. V. B. Norman they were popular in Europe even until $1585 .{ }^{17}$ On many altar-pieces painted in the workshop of the Master of the Polyptych from Gościeszowice swords with spherical pommels - forms of medieval origin - were also often represented ${ }^{18}$ (Fig. 3).

The growing importance of infantry at the end of the $15^{\text {th }}$ century resulted in great popularity of the pole arms on battlefields. Archaeological sources, iconography and original artefacts from museum collections from the beginning of the $16^{\text {th }}$ century confirm the longer popularity of various forms of pole arms (Awl-pikes, Halberds, Morgensterns), in shapes also used in the earlier period ${ }^{19}$ (Fig. 5:2). Note the spear head excavated during the underwater survey in Danków, Strzelce-Drezdenko District which could be dated to the mid- $16^{\text {th }}$ century. ${ }^{20}$ Changes in infantry tactics, related to the rapid development of firearms, caused that in the mid- $16^{\text {th }}$ century, staff weapon was increasingly losing its military purpose in favour of a decorative, ceremonial or hunting function. There is a massive spearhead (43 cm in length) from the collections of the Archaeological Museum of Mid-Odra River Region, of an undetermined find place, in form characteristic already for the mid- $16^{\text {th }}$ century. It has a large, deltoid-shaped blade (30 $\mathrm{cm}$ in length) with a strong central rib. The socket, octagonal in section, was provided with rectangular opening (Fig. 4). The latter was probably used to fasten a crossbar (Germ.: Knebel) made of bone antler, wood or iron by means of a leather thong. This element of boar- or bearspears, was supposed to stop an animal charging often in hunting conditions, preventing the hunter from being attacked. It was also designed to prevent the blade from penetrating the animal's body too deeply, to be able to withdraw the weapon quickly and strike again. According to scholars, spears with a movable crossbar, attached to the shaft through a thong, pulled through a notch on the socket, were supposed to not appear earlier than the end of the $16^{\text {th }}$ century. ${ }^{21}$ However, earlier examples of the use of this type of construction

${ }^{16}$ Geßler 1911; Oakeshott 1980, 146-149; Bosson 1982; Wanke 2009; Michalak 2019, 96.

${ }^{17}$ Norman 1980, 245-246.

${ }^{18}$ Michalak 2019, 94.

${ }^{19}$ Michalak 2019, 140-148.

${ }^{20}$ Chudziak et al. 2011, Fig. 35:a.

${ }^{21}$ Diener-Schönberg 1905, 347-348; Marek 2009, 104. 


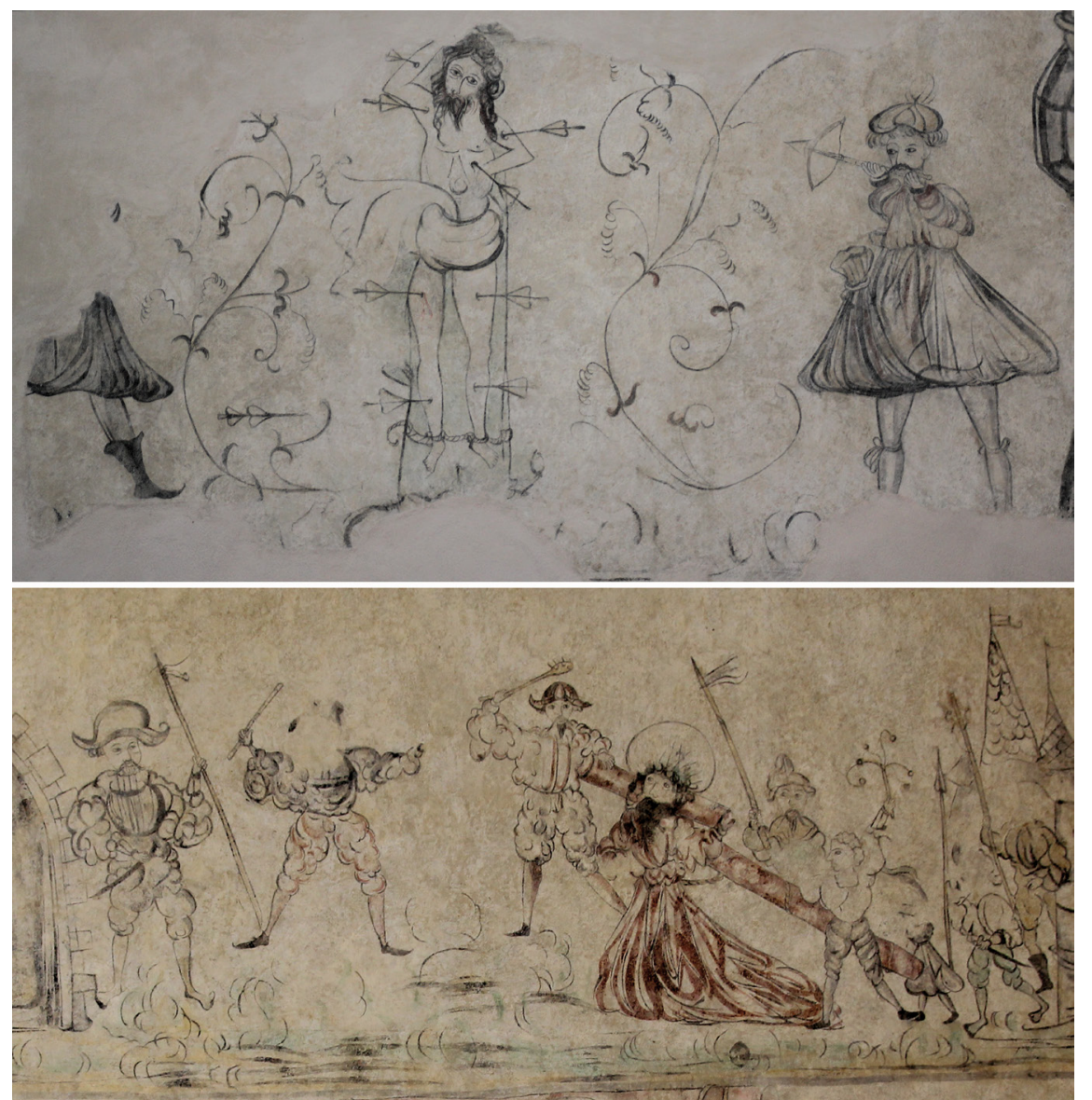

Fig. 5. Martyrdom of St. Sebastian and Carrying the cross scenes from frescoes painted on the eastern wall in the Parish Church of St. John the Baptist in Międzyrzecz. c. 1545. Photo R. Patorski.

in hunting spears are also known from the iconography of the early $16^{\text {th }}$ century. ${ }^{22}$ Artefacts with polygonal sockets and deltoid-shaped blades were used constantly in the Modern Period; for instance examples from the collection of Styrian Armoury in Graz comes from the $4^{\text {th }}$ quarter of the $16^{\text {th }}$ century. ${ }^{23}$ Due to the powerful blade this type of weapon could have been successfully used not only during hunting, but also on the battlefield. These spears were employed quite often in combat, especially by support personnel, sentries and other rear echelon troops. A spear with a movable bar depicted on the woodcut of Altdorfer, from his series Triumphal Procession of Emperor Maximilian, dated to 1517, was shown in the hands of a wagon soldier. ${ }^{24}$ The so-called Bärenspiess or Schweinspiess appears occasionally in arms inventories of castles in the Habsburg lands (see for example the Zeugbücher of Maximilian I). ${ }^{25}$

At this point, we would also like to draw attention to the need for more careful analysis of the context of the discovery of artefacts of forms commonly regarded

\footnotetext{
${ }^{22}$ Troso 1988, 107, Fig.1; Waldman 2005, Fig. 120.

${ }^{23}$ Krenn 1997, 56-57.

${ }^{24}$ Waldman 2005, 201, Fig. 161.

${ }^{25}$ BSB 1502. See Lazar 2017, 70.
}

as medieval. Very often, loose finds are automatically assigned to the medieval period. The bolts excavated in the castle in Międzyrzecz, with close analogies among $15^{\text {th }}$-century specimens, which were discovered in a well-defined $17^{\text {th }}$ century context, can serve here as an example ${ }^{26}$ (Fig. 6). Crossbows were used continuously in the Modern Period, not only during hunting ${ }^{27}$ (Fig. 5:1), and this is confirmed also by archaeological finds. ${ }^{28}$ Form of the bolts have not significantly changed until the $17^{\text {th }}$ century. ${ }^{29}$ Universal types of axes - regardless of whether they were used during the fight or not - were also employed frequently during the Modern Period..$^{30}$

Changes that took place on the battlefield at the end of the $15^{\text {th }}$ and the beginning of the $16^{\text {th }}$ century, with the growing importance of professional infantry, were not without impact on the form of arms and armour

\footnotetext{
${ }^{26}$ Banach et al. 2015, 275-276.

${ }^{27}$ E.g. Lüken 2019, 34-41.

${ }^{28}$ König et al. 1995, 159; Marek 2014, 24.

${ }^{29}$ Breiding 2013, 121-124.

${ }^{30}$ Łaszkiewicz and Michalak 2007, 114, Fig. 5:3; Kołosowski 2009, Fig. 7; Chudziak et al. 2011, Fig. 35:b-d; Michalak and Wawrzyniak 2011, Figs. 3 and 4.
} 


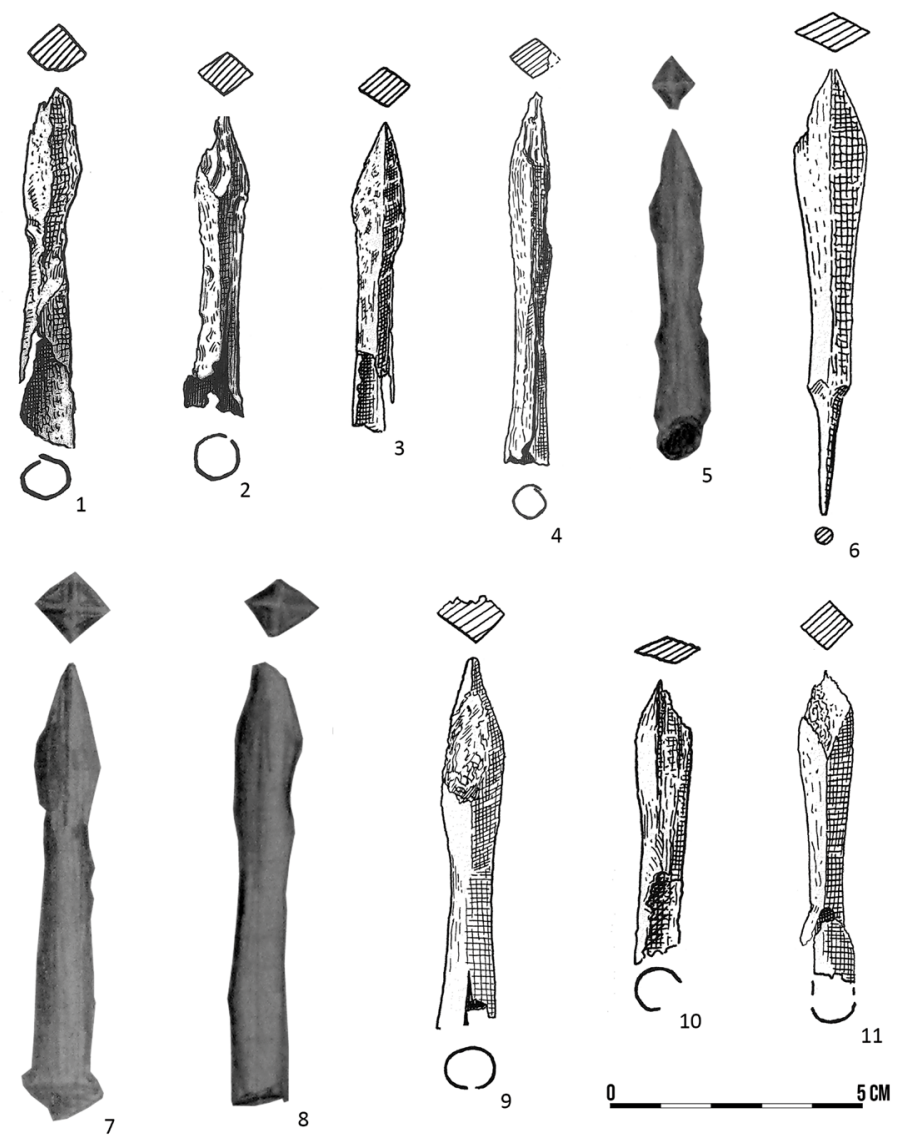

Fig. 6. Medieval reminiscences: crossbow bolts excavated from the baroque period strata in the castle in Międzyrzecz, $17^{\text {th }}$ century (1-11: Z54/217-218, Z54/222, Z54/224, Z54/473-475, Z54/482, Z54/563, Z54/579-580). After the archive of the Institute of Archaeology and Ethnology, Polish Academy of Science, Poznań Branch.

used during this period. The influence of civil fashion on armour was also significant. However, changes in various regions of Europe appeared gradually. Observations on iconographic sources from the borderland of Silesia, Greater Poland, Brandenburg and Lusatia, allow noticing the coexistence of the elements of Gothic plate defences together with modern innovations increasing the protection and comfort of people wearing armour at the beginning of the $16^{\text {th }}$ century. An example is the armour depicted on the effigy of Heinze von Röder $^{31}$ where, apart from the obviously Gothic: two-part breastplate, engrailed pauldrons of reptilian fashion, German sallet, there are also a long (extending almost to the knees), multi lamed fauld and rounded couters $^{32}$ (Fig. 7:2). Kin testimony can be found on the quarter from Dzieduszyce, Gorzów District from the beginning of the $16^{\text {th }}$ century. Apart from strictly old

\footnotetext{
${ }^{31}$ Captain (Hauptmann, hetman) of Kottbus in Lusatia, participant in the tournament organised in 1512 by Elector Joachim I of Brandenburg, in Ruppin alongside dukes of Saxony, Brandenburg and Braunschweig and the Captains of Alt- and Neumark - Brzustowicz 1997, 34.

${ }^{32}$ Czechowicz 2003, 140, cat. no. 88; Michalak 2019, 30, 52, P1. 23:1-2.
}

forms: visored sallets, bisegmented breastplates, parts of the vambrace have evidently gentle lines. ${ }^{33}$

Fluted armour (often called Maximilian), is considered by many scholars as the first fully modern form of armour. ${ }^{34}$ German armourers adopted there the fuller, more rounded forms favoured in Italy. ${ }^{35}$ According to some arms and armour historians in the new style, the shallow parallel channels that covered almost the entire armour were not only decorative but actually strengthened the metal. ${ }^{36}$ Other studies rather perceive them as a result of contemporary fashion. ${ }^{37}$ To compensate the deficiencies of such protection the analysed armours were often quenched and tempered. ${ }^{38}$ Fluted armour appears to have been a specialty of Nuremberg, ${ }^{39}$ but was also produced on a large scale in Italian and other South German workshops.

\footnotetext{
${ }^{33}$ Michalak 2019, 31, P1. 24:3-4.

${ }^{34}$ Grancsay 1928, 219; Bosson 1958, 89-90.

${ }^{35}$ Mann 1929, 219; Blair 1958, 115-116.

${ }^{36}$ Grancsay 1964, 15; Żygulski Jr. 1975, 151.

${ }^{37}$ Mann 1929, 217; Thomas 1937, 139-158.

${ }^{38}$ Williams 2003, 229-331, 499, 505-508, 569-575.

${ }^{39}$ Mann 1929, 218.
} 


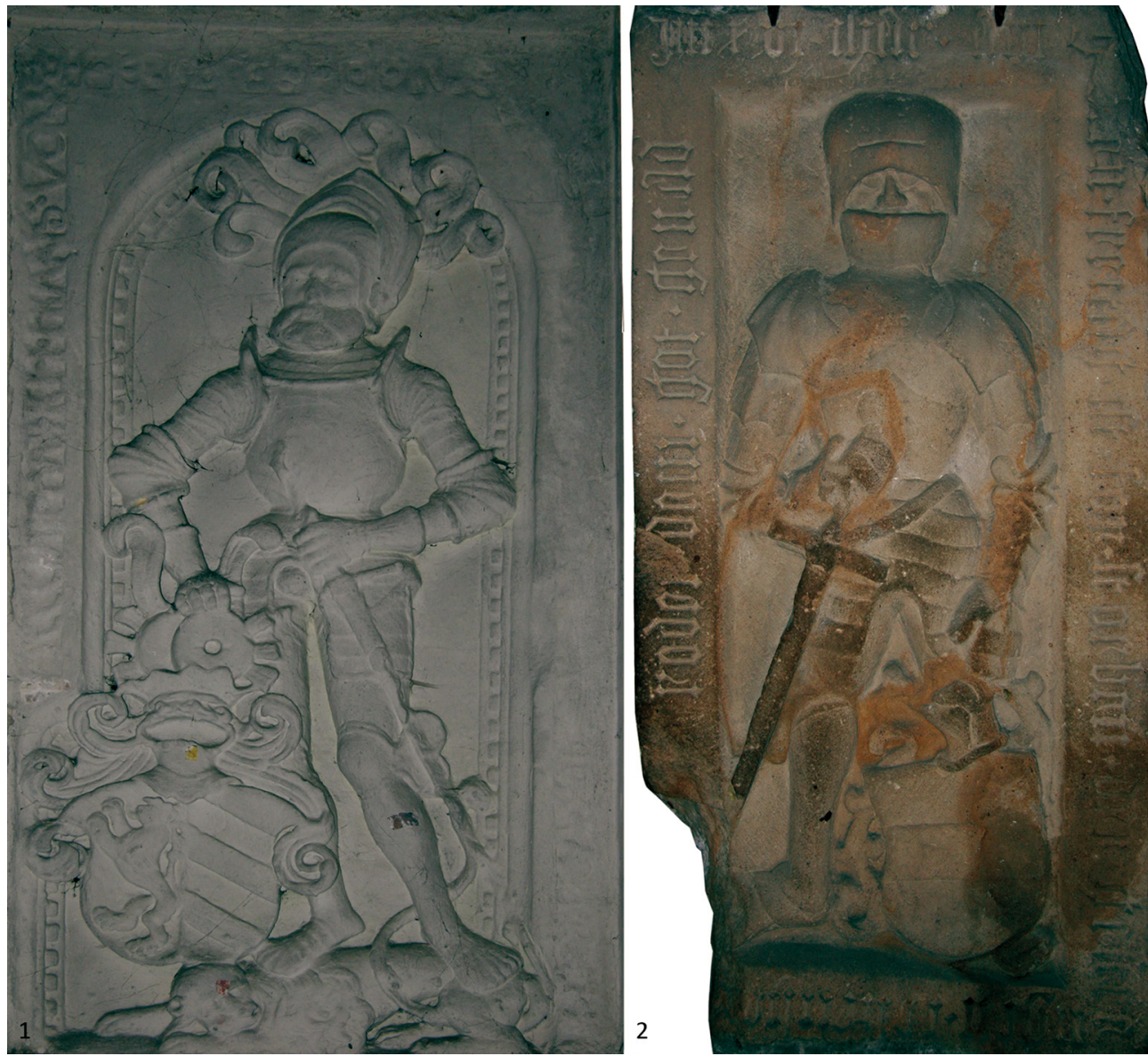

Fig. 7. Depictions of modern period innovations in arms and armour: 1 - effigy of Franc von Rothenburg from the church of the Assumption of Our Lady in Leśniów Wielki, c. 1532; 2 - Effigy of Heinze von Röder († 1517) from the Parish Church of the Visitation of Our Lady in Lubsko, after 1517. Photo A. Michalak.

However, in the light of the iconography of area in question, they were not very popular and appeared a bit later than in the rest of Europe. The earliest, known example is most likely the armour from the effigy of the mayor of Lubsko, Frans Rothenburg, from the church of the Assumption of Our Lady in Leśniów Wielki, Zielona Góra District dated to c. 1530. It is covered with a thick layer of plaster, which makes the full recognition of all its elements difficult. ${ }^{40}$ The waist of the globose breastplate is still slender (like medieval ones), but it has no placard. Decoration in the form of a single spray of flutes originating at a common point in the middle of the waist and radiating arched up and out across the chest. Fluting appears also on the pauldron and the cuff of the gauntlet. The lower abdomen and upper thighs are protected by an elongated lamed fauld. The helmet has a modern, fully enclosed form with a beaked visor attached to the lower part of the

${ }^{40}$ For this reason, I previously thought that this type of armour appeared in area in question not earlier than in 1545, Michalak 2019, footnote 72. Closer inspection of the monument from Leśniów Wielki carried out in 2019, have revealed the presence of a characteristic fluting. cheek protections. The upper part of skull is decorated with fluting and has a large plume of ostrich feather. Arm- and leg- defences are also of transitional form: symmetrical pauldron with sword breaker, but without gardbrace, multi-lamed vambrace and rounded couter. Surprisingly, instead of mitten gauntlets, traditional in the so-called Maximilian style, Frans wears a fingered gauntlet. Undecorated cuisses and greaves, poleyns with side wings and armoured sabaton in the form of bear's paws are also recognisable in this figurative source. The sword from the analysed effigy, with its straight cross and its pear-shaped pommel, is still medieval in form ${ }^{41}$ (Fig. 7:1).

The armour depicted on the tombstone should be considered as a transitional form of the so-called Maximilian style. As the sword hilt on the effigy covers more or less exactly the area where one would expect to see a lance rest, it is not possible to establish whether combat armour was depicted on this monument. The decoration of the breastplate is called in the literature the fan

${ }^{41}$ The German-style longsword remained a very popular weapon at the time and the traditional German school of fencing thrived into the late $16^{\text {th }}$ century. 


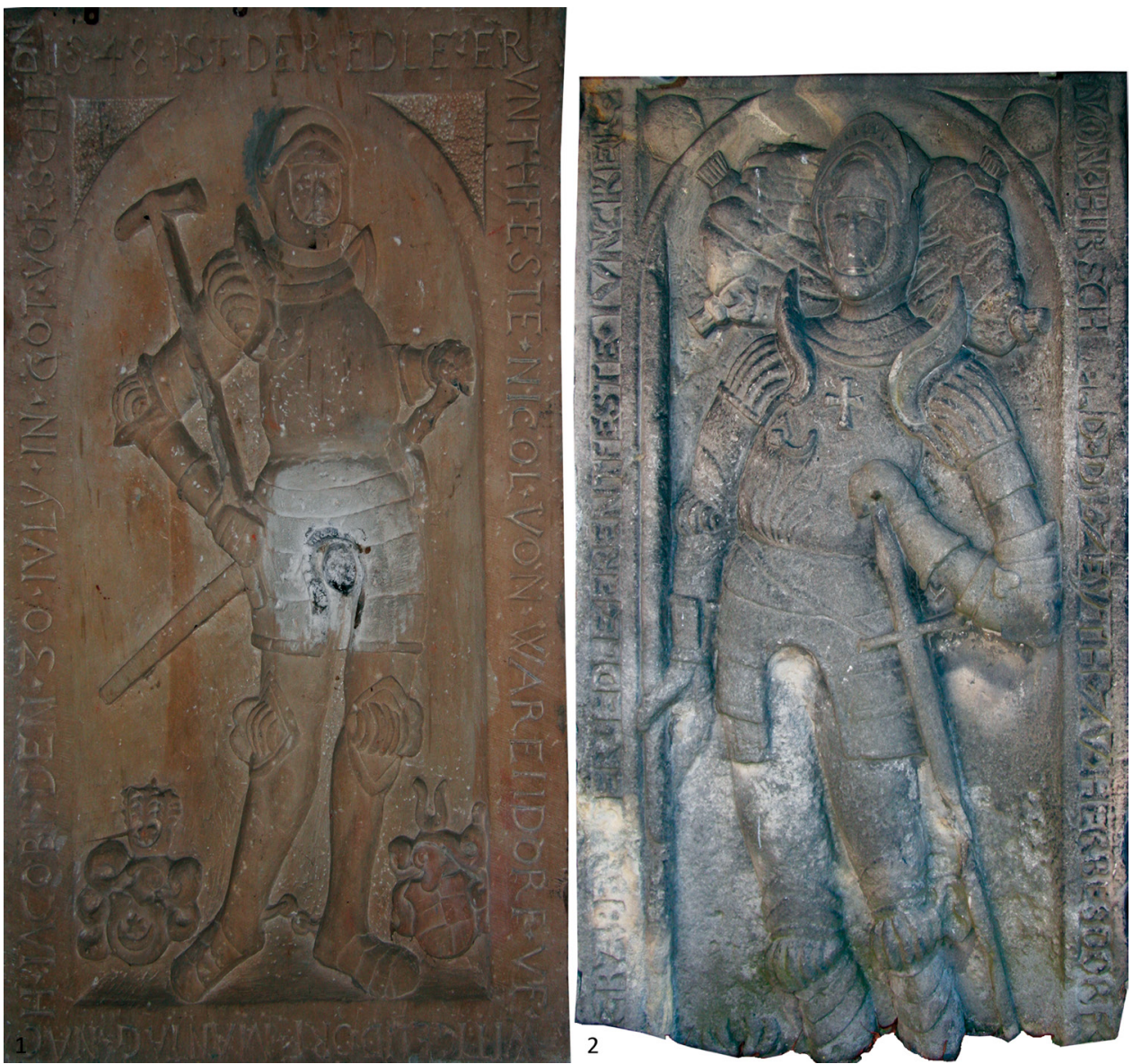

Fig. 8. Depictions of modern period armour with fluted elements: 1 - effigy of Nicolas von Warnsdorf $(\dagger 1548)$ from the church of St. Michael Archangel in Witków; 2 - effigy and Balthasar von Knobelsdorf $(\dagger 1543)$ from the church of St. Nicholas in Jelenin. Photo A. Michalak.

motif..$^{42}$ Note that in the Maximilian portrait from 1496 by Bernhard Striegel, the future emperor wears a chest defence with such a pattern, but the other elements of his armour suit still have a Gothic form. ${ }^{43}$ These transitional forms of body defences are known from pieces of art dated to century $1520 .{ }^{44}$ Original breastplates

${ }^{42}$ Klapsia and Thomas 1937, 147, Fig. 157:i; Cieśla 2018, 18-21.

${ }^{43}$ Lüken 2010, 240-241, cat. no. 14.I. Other iconographic evidence: e.g. Johann Bibra $(† 1473)$, but his tomb must have been executed thirty years later by Tilman Riemenschneider, Mann 1929, 220, P1. LXVII:3.

${ }^{44}$ E.g. the tombstone of Wolf(f) the Younger Kämmerer von Worms, called von Dalberg $(\dagger 1522)$ executed by L(i)enhart Seyfer, from Katharinenkirche, Oppenheim, Rheinland-Pfalz, dated to 1517-1522, Mann 1929, 220, Pl. LXV:1; Ecce Homo, epitaph Andreas Hirde $(\dagger 1518)$ by Peter Schro, from Kaiserdom St. Bartholomäus, Frankfurt am Main, Hessen, dated to c. 1518; Funerary Monument for Herrmann VIII ( $\dagger$ 1535) by Peter Vischer the Elder from Baptist Chapel, Collegiate Church in Römhild, Thuringia, c. 1515; the figure of St. George made in workshop in the town of Villach in Carinthia from the Filial church of St. Leonard in $\mathrm{Mu}-$ rau and the figure of St. Florian, made in Carinthia from Joanneum Graz, Alte Galerie - Krenn and Rabensteiner 1992, cat. no. 62-63i, Figs. 31 and 74. Emperor's Maximilian I Zeughausbuch of the Tyrol, fol. $87 \mathrm{v}$, c. 1512/1517, Vienna, Kunsthistorisches Museum, Kunstkammer, Krause 2017a, 30, III.7. come from the second decades of the $16^{\text {th }}$ century. One needs to mention here half-armour from the workshop in Innsbruck, from the collection of the counts of Pszczyna, ${ }^{45}$ now in the collection of Deutsches Historisches Museum, Berlin (W 1051a-g). ${ }^{46}$ Another, very similar breastplate is exhibited in the National Museum of Wrocław (IX-877). ${ }^{47}$ Analogous specimens, of which at least two were made in Nuremberg, can also be found in the collection of the Kunsthistorisches Museum, Vienna (A716, A345, A2155)..$^{48}$ Another half armour with this decoration made in either Mühlau or in neighbouring Innsbruck by Christian Schreiner the Younger, armourer recorded between 1499-1528, is preserved in the collection of the Metropolitan Museum of Art, New York (inv. no. 1991.4). It was most likely made c. $1505-1510 .{ }^{49}$ Specific location of pivots for the visor on both sides of the helmet, is unusual for both

${ }^{45}$ Cieśla 2008, 197-198.

${ }^{46}$ Müller and Kunter 1984, cat. no. 23.

${ }^{47}$ Cieśla 2008, 198; Witecki 2013, 305. In this work dated too early to c. 1500 .

${ }^{48}$ Thomas and Gamber 1976, 235-237.

49 Thomas and Gamber 1954, 62; LaRocca 1991, 23. 


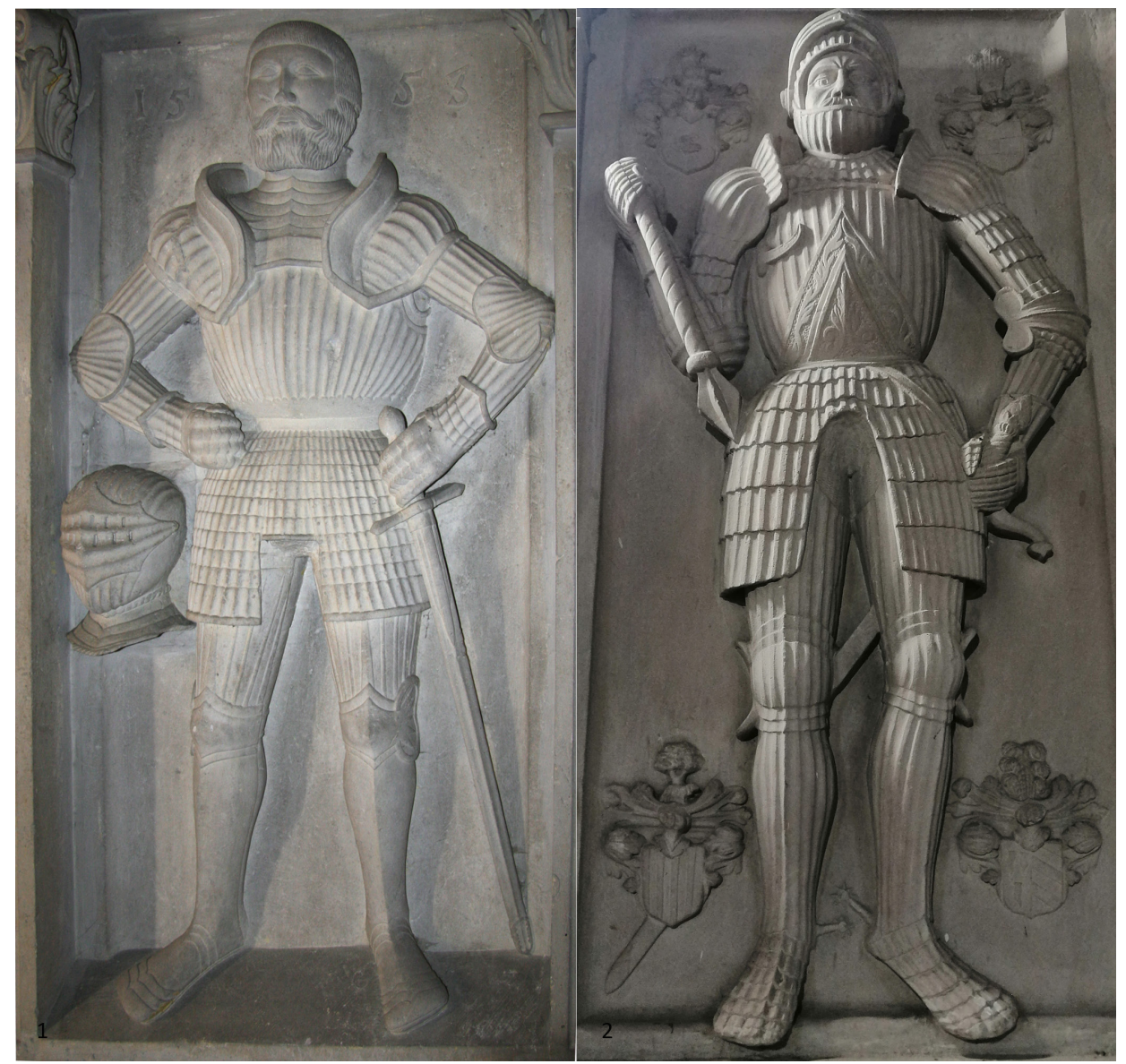

Fig. 9. Depictions of fluted armours in Maximilian style: 1 - Funerary Monument for Francke of Nechern from John the Baptist church in Chichy, c. 1553; 2 - Funerary Monument for Balthasar Rechenberg († 1567) from the church of St. Laurence in Borów Wielki. Photo A. Michalak.

armets and sallets, among which many from the first quarter of the $16^{\text {th }}$ century, are decorated similarly to depicted one..$^{50}$ Comparable helmet with a plume is visible on the of effigy of Jan of Krużlowa from Cistercian Abbey of Virgin Mary and St. Wenceslaus in Cracow-Nowa Huta, dated to c. $1532 .{ }^{51}$

Further evolution in this form proceeded by adding parts of heavily fluted arms and legs defences. These changes are visible in the suits of armour depicted on the effigies of Nicolas von Warnsdorf ( $†$ 1548) from the church of St. Michael Archangel in Witków (Fig. 8:1) and Balthasar von Knobelsdorf $(\dagger 1543)$ from the church of St. Nicolas in Jelenin (Fig. 8:2). Note also that on both images the individuals already have classic Maximilian style mittens.

Fully developed fluted armour is depicted on the sandstone grave slab of Francke of Nechern from John the Baptist church in Chichy. The monument is dated to 1553 , however according to art historians, it portrays protections used during the life of the depicted

\footnotetext{
${ }^{50}$ Mann 1929, Pl. LXXVII; Mann 1962, 102; Puype and Stevens $2010,42-45$

${ }^{51}$ Mrozowski 1994, 211-212, cat. no. I.85.
}

knight. ${ }^{52}$ His breastplate is almost completely embellished with broad grooves in form of whole beam pattern. The poleyns, greaves and sabatons in this effigy are undecorated. Nachern's German armet is also covered with dens fluting (Fig. 9:1). The second, very similar armour was depicted on the sandstone grave slab of Balthasar Rechenberg from the church of St. Laurence in Borów Wielki († 1567). ${ }^{53}$ Broad and deep fluting is covering all parts of his body defences. The elements that distinguish Rechenberg's effigy are the presence of a bevor, the decoration of all elements with grooves and the breastplate ornamented with a motif of a triangle arranged inside triangle with floral pattern (Fig. 9:2). Rechenberg's weaponry from this depiction (long sword and mace) is also different from the one depicted on Nachern's effigy. Armour of this kind is known from iconography dated to c. $1530-1540 .{ }^{54}$

\footnotetext{
${ }^{52}$ Kębłowski 1967, 97.

${ }^{53}$ Andrzejewski 2004, 139-140, Fig. 6:a.
}

${ }^{54}$ E.g. the funerary monument of the King Sigismund I the Old of Poland by Bartolomeo Berecci from Wawel, Cracow, dated to c. 1530 - Żygulski Jun. 1975, Fig. 61. Sandstone Funerary Monument to Balthasar Truchsess von Wetzhausen from 

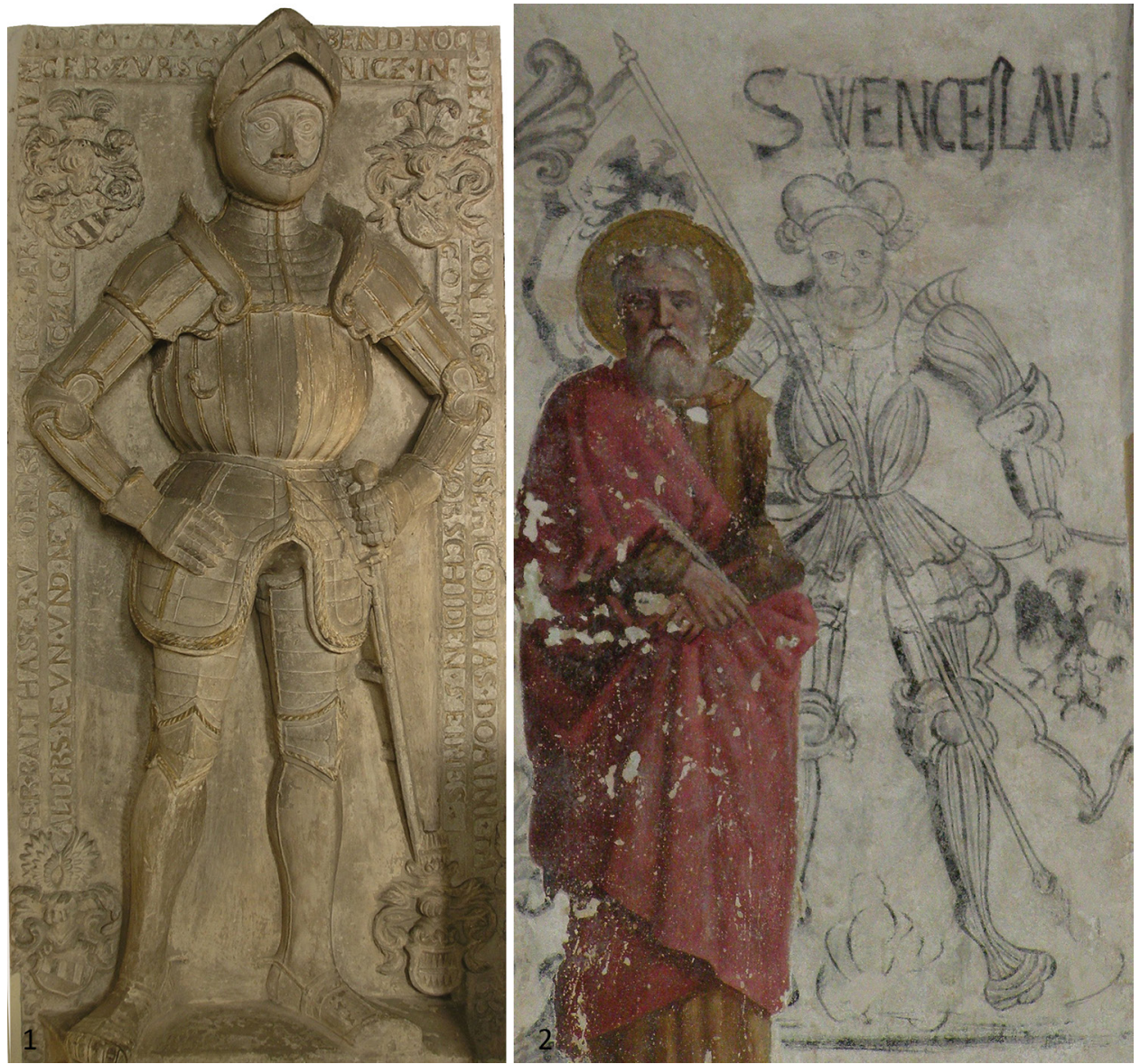

Fig. 10. Depictions of modern period fluted armours: 1 - effigy of Balthasar von Kittlitz $(† 1553)$ from the church of St. Martin in Świdnica. Photo R. Patorski. 2 - St. Wenceslaus from frescoes painted on the eastern wall in the Parish Church of John the Baptist in Międzyrzecz. c. 1545. Photo A. Michalak.

Quite quickly, fluted armours, the reminiscence of the Maximillian style, popular in various regions of the Empire throughout the $16^{\text {th }}$ century and also at the beginning of the $17^{\text {th }}$ century, ${ }^{55}$ became fashionable in many variants and varieties also in analysed area. Flutes were transformed here into wide bands, with gilded ridges, decorated with a rope motif or etched appliqué. It should be mentioned here two evidences that testify the use of this type of body defences. First, we need to discuss the effigy of Balthasar Kittlitz $(\dagger 1553)$ from the church of St. Martin in Świdnica ${ }^{56}$ (Fig. 10:1). Similar armour appears on the polychrome with depiction of St. Wenceslaus from the Parish Church of John the Baptist in Międzyrzecz. Frescoes from there were probably painted in 1545. Their foundation can be attributed to the starosta of Międzyrzecz, Laurentius Myszkowski, who bore the Jastrzębiec coat of arms, from the Lesser

the church of St. Martin, Wetzhausen, from c. 1540 and Funerary Monument for Claus von Heßberg $(\uparrow 1539)$ by Bernhard Friedrich from Parish Church of St. Mary Magdalene in Münnerstadt, dated to c. $1530-1540$.

${ }_{55}^{55}$ Thomas 1938; Marek and Bis 2013, 534.

${ }^{56}$ Michalak 2012, 24-25.
Poland, what also explains why this saint, not popular in Greater Poland, was depicted there ${ }^{57}$ (Fig. 10:2).

Roundness of forms, typical for modern armours, is also noticeable in body defences depicted on the votive image of von Rothenburg family from the church of the Visitation of Our Lady in Lubsko. ${ }^{58}$ The condition of this painting, severely limits the possibility of precisely determining the form of the breastplate (Fig. 12). However, it is clearly visible that the waistline is no longer as deep as in the Gothic style. The better-preserved lower part of the painting allows clearer observation of construction details of the skirt and leg protection of the Rothenburg family members. The fauld, reaching beyond the hips, was complemented by triangular tassets. The skirt (and cuisses from the last depicted member) which gives the impression of being made from a series of small rectangular plates is in particularly interesting form. It seems that in this image a fauld made of hooped lames (in the analysed case five-six rows) was portrayed, which by means of engraving, embossing, etching or grooving, divided by vertical lines into

\footnotetext{
${ }^{57}$ Patorski 2010, 43.

${ }^{58}$ Jankowski 2005, 19, cat. no. 64.
} 

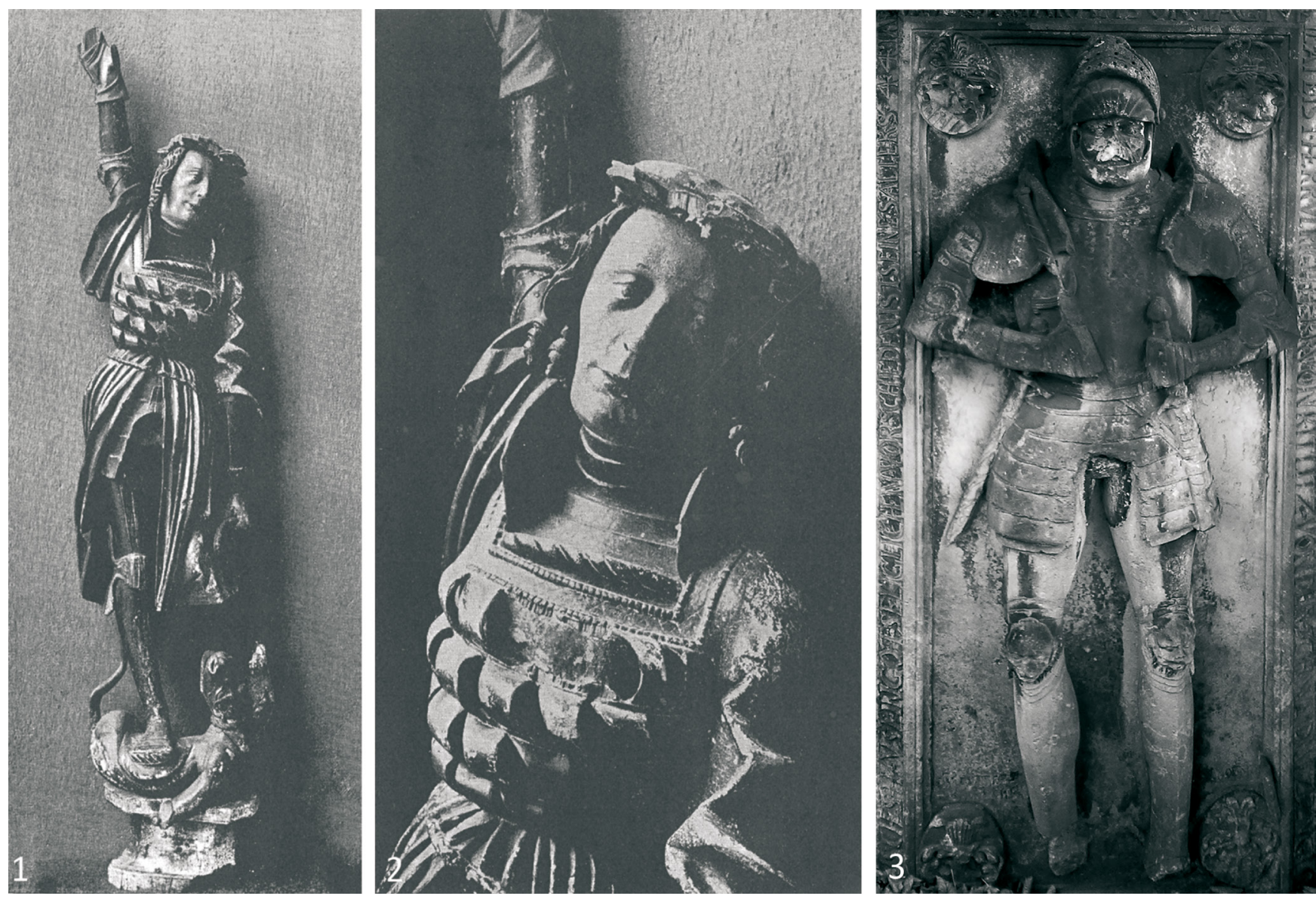

Fig. 11. Depiction of costume armour (1-2) and grotesque elements of leg defences (3): 1-2 - figure of St. George, church in Dzieduszyce (now lost), c. 1520s. After Reißmann 1937; 2 - effigy of Ulrich von Kittlitz from Świdnica († 1568) at the Parish Church of St. Michael Archangel in Nowa Sól. Photo A. Michalak.

smaller rectangular plates..$^{59}$ An analogous method of decoration is known from many products of South German armourers, dated to the very beginning of the $16^{\text {th }}$ century. ${ }^{60}$ This construction was also used in the foot combat armour made for King Henry VIII of England. ${ }^{61}$ In this armour the surface of the plates from skirt (reaching till the knees) was decorated with etched and engraved Tudor roses and floral decoration with plain fields alternately. Emperor Charles V also owned few types of armour with such skirts. ${ }^{62}$

Different style of the armour making from the $16^{\text {th }}$ century represent body defences portrayed on the statue of St. George from the church in Dzieduszyce, dated to the beginning of the $16^{\text {th }}$ century. ${ }^{63}$ The breastplate is convex in the lower part. In its upper section there is a quadrangular cutout decorated with a notched trimming for a five lamed gorget, reaching

\footnotetext{
${ }^{59}$ Michalak 2019, 53-54.

${ }^{60}$ Mann 1929, Pl. LXXVIII:1; Thomas and Gamber 1954, 54, cat. no. 88; Scalini 1996, 128, Fig. 14; Eaves 2002, 127-128.

${ }^{61}$ Blair 1995, Figs. 7-9; Richardson 2009, 124, 126-127.

${ }^{62}$ Calvert 1907, Pls. 24-25, 27, 30.

${ }^{63}$ Reißmann 1937, Figs. 129-130; Michalak 2019, 54.
}

the chin. The lower line of the opening is decorated with horizontal, twisted trimming and there are sword breakers on sides. The front part of the breastplate is decorated with four rows of half-round, wide rollers, which are cut to the base with diagonal lines. They cover almost the entire breastplate area. The spaces between them are embellished with notched lines. To the bottom part of the chest defence a five lamed fauld, with deep cutout for horse riding was attached (Fig. 11:1-2). This is undoubtedly an element of costume armour. It seems that all the characteristic decoration of the torso defence is related to Renaissance civil fashion where clothes comprising layers of differently coloured or textured cut textiles were very popular. ${ }^{64}$ This decoration resembles to the form of ornamentation appearing on several examples of the ceremonial armour, intended not for combat use, but during tournaments, festivals and parades. ${ }^{65}$ Made most likely in South German workshops ${ }^{66}$ they came into use in the first decade of

${ }^{64}$ Dean 1926, 260; Grancsay 1931; Grancsay 1950; Krause 2017b, 31-32.

${ }^{65}$ Krause 2017c, 58.

${ }^{66}$ Cieśla 2015, 34-35. 


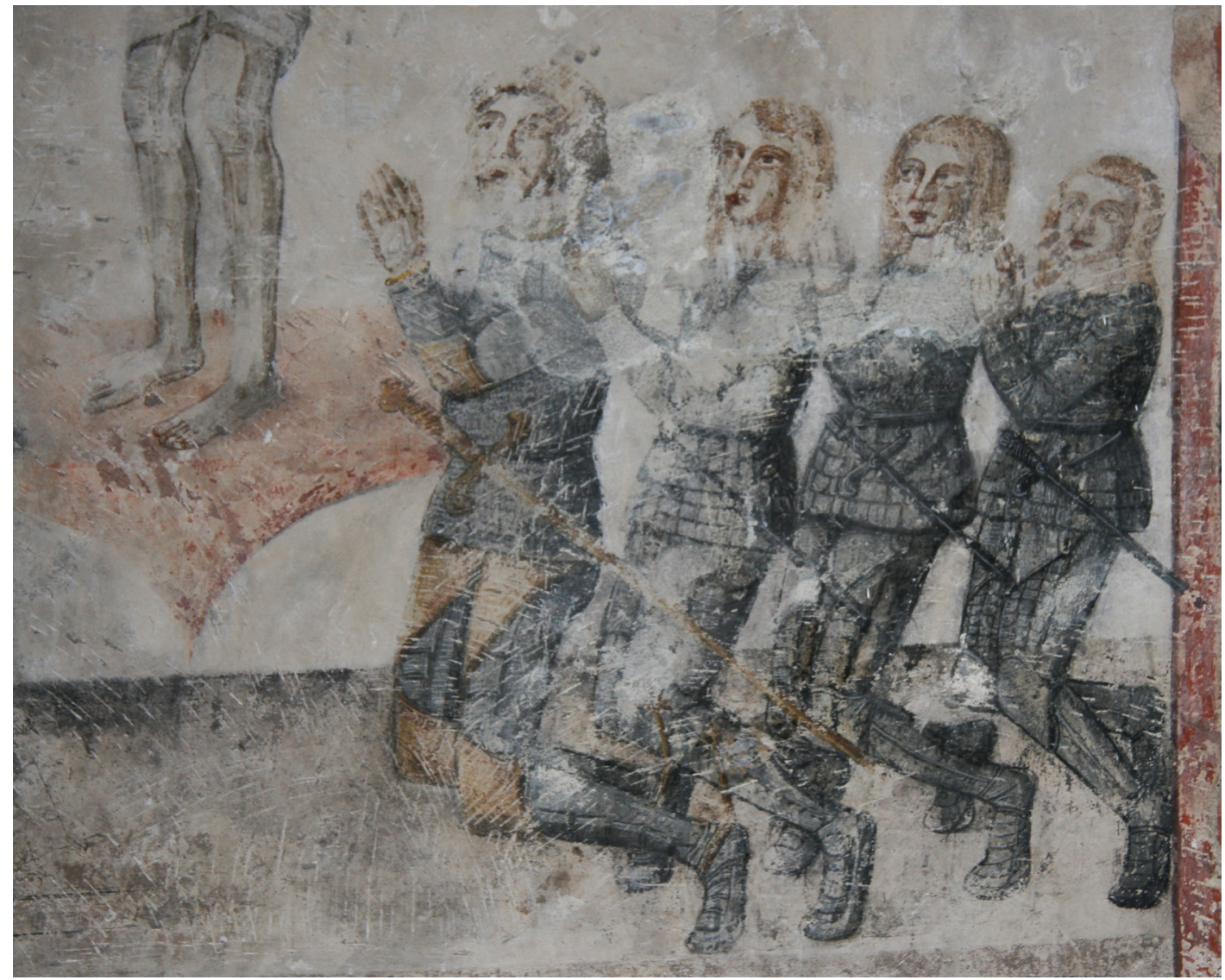

Fig. 12. Depictions of modern period arms and armour from votive image of von Rothenburg family from the church of the Visitation of Our Lady in Lubsko, c. 1520. Photo A. Michalak.

the $16^{\text {th }}$ century, but they became out fashioned already in the 1530s. ${ }^{67}$ The armour from the Vienna Armoury (inv. no. A186), made in Innsbruck by Hans Rabeiler for the emperor Charles V, c. $1511 / 1512^{68}$ is a close parallel to this breastplate. A similar specimen kept in the Wallace Collection (inv. no. A29) is dated to the $1^{\text {st }}$ quarter of the $16^{\text {th }}$ century ${ }^{69}$ or precisely to $1520 .^{70}$ Another armour with puffed and slashed decoration is kept in the Musée de l'Armée in Paris (inv. no. G 13). ${ }^{71}$ The Deutsches Historisches Museum (inv. no. 2326) poses armour with this kind of decoration, however of simplified form, dated to c. 1510-1515..$^{72}$ This kind of armour attributed to Hans Rabeiler, is also kept in the Bernisches Historisches Museum (inv. no. 104). ${ }^{73}$ It is dated to 1510-1515. Puffed and slashed decoration in the mentioned suits of armour also occurs on tasetts and pauldrons, which, due to being concealed by the

${ }^{67}$ Klapsia and Thomas 1937, 156; Thomas and Gamber 1949, 40; Blair 1958, 116; Oakeshott 1980, 78-79; Cieśla 2015, 10-13.

${ }^{68}$ Thomas and Gamber 1954, cat. no. 53; Thomas and Gamber 1976, 215, Pl. 111.

${ }^{69}$ Laking 1920, Fig. 1042.

${ }^{70}$ Mann 1962, 27.

${ }^{71}$ Niox 1917, Fig. X; Cieśla 2015, 36-37.

${ }^{72}$ Quaas 1992, 65-66, Fig. 70.

${ }^{73}$ von Closs 1930, 150; Thomas and Gamber 1949, 45-46, Fig. 8. mantle, cannot be confirmed on the depiction from Dzieduszyce. The collected data allow determining the time of creation of this figure for $1520 \mathrm{~s}$.

At the end one should also note the presence of parts of defences inspired by Italian armour makers and mannerism on iconographic sources from the $2^{\text {nd }}$ half of the $16^{\text {th }}$ century. The turn towards the ancient traditions in Italy - a distinctive feature for the Renaissance - resulted there in recreation of armours inspired by antique. ${ }^{74}$ Defences alla'antica were often embellished with masks. ${ }^{75}$ South German armour makers, especially in Augsburg, inspired by Italian achievements, tried to give their own form to the art of metal embossing. ${ }^{76}$ The lionlike poleyns depicted on the effigy of Ulrich von Kittlitz from Świdnica $(\dagger 1568)$ at the Parish Church of St. Michael Archangel in Nowa Sól, are most likely the embodiment of these trends (Fig. 11:3) Parts of leg defences embossed with such motif are known form original suits of armour dated to $1540-1550 .^{77}$

\footnotetext{
${ }^{74}$ Hayward 1979; Pfaffenbichler 1989, 236-237.

${ }^{75}$ LaRocca 2004, 35; Springer 2010.

${ }^{76}$ Klapsia 1937.

${ }^{77}$ Norman 1974; Pyhrr et al. 1998, cat. no. 53, 62; Jefimov 2002, cat. no. 19 .
} 
Completing remarks regarding offensive arms, one needs to admit that in general there is lack of knowledge about the weapons used in the $1^{\text {st }}$ half of the $16^{\text {th }}$ century in the area in question. There are practically no archaeological finds, and the arms depicted in iconography are quite schematic. It should be noted that the most important side arms of the modern period - short single handed sword, the so called knightly sword (or cavalry sword) ${ }^{78}$ and long swords appeared on the effigies of this region not earlier than in the beginning of the $2^{\text {nd }}$ half of the $16^{\text {th }}$ century (Figs. 7-10). Some nobles could still use weapons inherited from their ancestors. ${ }^{79}$ We should note the presence of small knives or bodkin pockets on the sword's scabbard, helpful in the knight's mundane activities; according to Norman, characteristic mainly for the period between 1520-1600 (Figs. 9:1 and 10:1). In this area, however, they were probably not very popular because they occur in only two depictions.

Beside the knightly swords, falchions were probably also in use. One of them was accidentally discovered during earthworks near the hospital in Henryków-Szprotawa. ${ }^{80}$ It has a wide and massive, single-edged blade. A clearly modern element in this weapon is a steel ring from the hilt decorated with triple engraved lines on the edges. Basing on analogies, it can be assumed that the falchion was made in the first quarter of the $16^{\text {th }}$ century, which is also confirmed by iconographic analogies. ${ }^{81}$

On the votive image of the Rothenberg family from the parish church in Lubsko, appears also another side weapon, very popular in the modern period. It has a very narrow blade and an S-shaped quillon (Fig. 12). The blade of this weapon suggests unambiguous associations with rapiers. The S-shaped crossguard as an element of rapiers and swords arrived in the south-eastern Europe in the $2^{\text {nd }}$ half of the $15^{\text {th }}$ century ${ }^{82}$ and were used as their elements in whole Europe throughout the $16^{\text {th }}$ century and part of the $17^{\text {th }}$ century. ${ }^{83}$ Rapiers were usually tied to the saddle and used during horse fighting and later also hunting. ${ }^{84}$

Daggers are very rare in the $16^{\text {th }}$-century iconography of this region. They are only known from Ulrich

\footnotetext{
${ }^{78}$ Oakeshott 1980, 126; Marek 2008, 76-81.

${ }^{79}$ For example, in the armoury of the castle in Siedlisko, completed in 1618, the sword gained by Fabian von Schönaich from Ernest Brunswick during the Battle of Mühlberg in 1547, was still stored - Barth 1891, 20.

${ }^{80}$ Marek and Mucha 2006, 217.

${ }^{81}$ Michalak 2019, 104.

${ }^{82}$ Aleksić 2007, 97-104; Sijarić 2014, 128-135.

${ }^{83}$ Descamps 1913, 15, Photo 169; Wegeli 1929, cat. no. 239; di Carpegna 1969, cat. no. 213; Müller 2002, Fig. 47.

${ }^{84}$ Oakeshott 1980, 134; Müller 2002, 52.
}

von Kittlitz' tombstone, where a Renaissance quillon dagger was depicted (Fig. 11:3). Their role, as in the whole Silesia, ${ }^{85}$ was definitely greater than it could appear from assembled iconography.

Personal blunt weapons were undoubtedly of lesser importance. The evidence of their use comes from the discussed tombstones. Depicted flanged mace ${ }^{86}$ (Fig. 9:2) and war hammer (Fig. 8:1), could deliver the full force blow to the target and pierce the opponent's armour. Their form is typical for Renaissance specimens, known both from the original artefacts and iconography. ${ }^{87}$

To summarise, Gothic elements of arms and armour still exist in the iconography of the borderland until the $2^{\text {nd }}$ decade of the $16^{\text {th }}$ century. Archaeological finds of these elements occur occasionally in the strata dated to the $16^{\text {th }}$ or even to the $17^{\text {th }}$ century. Fully developed modern period arms and armour appear in iconography of this region not earlier that 1530 s. The assembled sources indicate that there were not serious delays in the introduction of arms and armour innovations into the area we have analysed. It can be concluded that the trends observed on their basis reflect the actual state of development in these areas. As a result of the revolutionary changes that took place in hand-held fire arms, from the mid- $16^{\text {th }}$ century, full armour begins to disappear from the battlefield. The battle of Pavia on 24 February, 1525 became a symbolic point, where the mass use of firearms by the Habsburg infantry against the French gendarmes decided the result of the battle. ${ }^{88}$ The process of the twilight of the knights began...

\section{Acknowledgements}

I am indebted to my friend and colleague Dirk H. Breiding - the J. J. Medveckis Associate Curator of Arms and Armour at The Philadelphia Museum of Art - for his information on the Monuments for Balthasar Truchsess von Wetzhausen, Claus von Heßberg and Herrmann VIII. I am also grateful to Ryszard Patorski, Międzyrzecz for providing me images of the frescoes from parish church in Międzyrzecz. Last, but not least I would like to thank Dr hab. Lech Marek, Institute of Archaeology of the University of Wrocław, for reading drafts of this paper and providing many helpful comments.

\footnotetext{
${ }^{85}$ Marek 2008, 31-37.

${ }^{86}$ Maces were probably depicted also on the effigies of Francke of Nachern and Ulrich von Kittlitz.

${ }^{87}$ Oakeshott 1980, 62-72; Kovács 2016, cat. no. 24, 62.

${ }^{88}$ Oakeshott 1980, 192.
} 


\section{Sources}

BSB. 1502. HSS Cod. Icon. 222, Arms inventories of Maximilian I. Bayerische Staatsbibliothek, Munich.

CDB. 1858. Codex Diplomaticus Brandenburgensis. Sammlung der Urkunden, Chroniken und sonstigen Quellenschriften für die Geschichte der Mark Brandenburg und ihren Regenten 31 (II/6), ed. A. F. Riedel, Berlin.

\section{Bibliography}

Aleksić M. 2007. Mediaeval Swords from Southeastern Europe. Material from $12^{\text {th }}$ to $15^{\text {th }}$ century. Belgrade.

Andrzejewski T. 2004. Pomniki sepulkralne Rechenbergów w powiecie nowosolskim. "Lubuskie Materiały Konserwatorskie" 2, 133-150.

Ayton A., Price J. L. 1995. The Military Revolution from a Medieval Perspective. In: A. Ayton, J. L. Price (eds.), The Medieval Military Revolution. State, Society and Military Change in Medieval and Early Modern Europe. London, New York, 1-22.

Banach B., Kurnatowski S. Urbańska-Łosińska A., Zamelska-Monczak K. 2015. Gród i zamek późnośredniowieczny. In: S. Kurnatowski (ed.), Międzyrzecz. Gród i zamek w wiekach IX-XIV. Wyniki prac wykopaliskowych z lat 1954-1961. Warszawa, 217-276.

Barth W. 1891. Die Familie von Schönaich und die Reformation. Beuthen.

Bäumel J. 1992. Tournaments of the Saxon Electors in the 16th Century. In: L. Rangström (ed.), Riddarlek och Tornerspel / Tournaments and the Dream of Chivalry. Stockholm, 350-351.

Blair C. 1958. European Armour; circa 1066 to circa 1700. London.

Blair C. 1995. King Henry VIII's Tonlet Armour. "Journal of Arms and Armour Society" 15(2), 85-108.

Bosson C. 1958. L'Armure á cannelures. "Armes Anciennes" 11(4), 89-107.

Bosson C. 1982. L'epée à deux main. In: K. Stuber, H. Wetter (eds.), Blankwaffen, armes blanches, armi bianche, edged weapons: Festschrift Hugo Schneider zu seinem 65. Geburtstag. Zürich, 45-56.

Breiding D. H. 2012. Rennen, Stechen und Turnier zur Zeit Maximilians I. In: C. Lagerwaard (ed.), "Vor Halbtausend Jahren...": Festschrift zur Erinnerung an den Besuch des Kaisers Maximilian I. in St. Wendel. St. Wendel, 53-84.

Breiding D. H. 2013. A Deadly Art: European Crossbows, 1250-1850. New York.

Brzustowicz B.W. 1997. Margrabia Jan z Kostrzyna i turnieje rycerskie. "Nadwarciański Rocznik Historyczno-Archiwalny" 4, 29-40.

Calvert A. F. 1907. Spanish Arms and Armour Being a Historical and Descriptive Account of the Royal Armoury of Madrid. London, New York.

di Carpegna N. 1969. Antichi Armi dal. Sec. IX al XVIII già Collezione Odescalchi. Roma.

Chudziak W., Kaźmierczak R., Niegowski J. 2011. Podwodne dziedzictwo archeologiczne Polski. Katalog stanowisk (badania 2006-2009). Torun.

Cieśla M. 2008. Broń renesansowa na Ślasku. Racibórz.

Cieśla M. 2015. Napierśnik i naplecznik kostiumowy z Muzeum Wojska Polskiego w Warszawie na tle zbroi tego typu. "Studia z Dziejów Wojskowości" 4, 7-56.

Cieśla M. 2018. Napierśnik zbroi z warsztatu mediolańskiego w kolekcji Muzeum Wojska Polskiego w Warszawie. Analiza porównawcza. "Studia z Dziejów Wojskowości" 7, 9-55.

Closs von G. 1930. Der Harnisch der Übergangszeit von der Gotik zur Renaissance (1495-1520). "Zeitschrift für Historische Waffen- und Kostümkunde" 12(7), 145-151.

Czechowicz B. 2003. Nagrobki późnogotyckie na Śląsku. Wrocław.

Dean B. 1926. Puffed and Slashed Armor of 1525. "Bulletin of the Metropolitan Museum of Art" 21(11), 260-264.

Descamps E. 1913. Catalogue des Armes Anciennes. Bordeaux.

DeVries K. 1996. Infantry Warfare in the Early Fourteenth Century: Discipline, Tactics, and Technology. Woodbridge.

Diener-Schönberg A. 1905. Knebel an Jagdblankwaffen. "Zeitschrift für historische Waffen- und Kostümkunde" $3,345-357$.

Eaves I. 2002. Catalogue of European Armour at the Fitzwilliam Museum. Cambridge.

Geßler E. A. 1911. Der Zweihänder. Eine waffengeschichtliche Studie mit besonderer Berücksichtigung Basels. "Anzeiger für schweizerische Altertumskunde" N.F. 12, 1910, 50-60. 
Goliński M. 2006. Ludzie, przyroda i gospodarka na Dolnym Śląsku (1526-1618). In: W. Wrzesiński (ed.), Dolny Ślask. Monografia historyczna. Wrocław, 189-225.

Grancsay S. V. 1928. Maximilian Armour. "The Metropolitan Museum of Art Bulletin" 23(4), 82-85.

Grancsay S. V. 1931. The Mutual Influence of Costume and Armour: A Study of Specimens in the Metropolitan Museum of Art. "The Metropolitan Museum of Art Bulletin" 3(2), 194-208.

Grancsay S. V. 1950. The Interrelationships of Costume and Armour. "The Metropolitan Museum of Art Bulletin" 8(6), 177-188.

Grancsay S. V. 1964. Arms and Armour. Allentown.

Hayward J. F. 1979. The Revival of Roman Armour in the Renaissance. In: R. Held (ed.), Art, Arms and Armour: An International Anthology. Chiasso, 144-163.

Jankowski A. 2005. Średniowieczne malarstwo ścienne na Ślasku u progu reformacji. Ikonografia - funkcje - styl. Bydgoszcz.

Jefimov J. G. 2002. Uzbrojenie i broń - katalog. In: A. R. Chodyński, E. Witkowicz-Pałka (eds.), 101 Arcydziet dawnych mistrzów XV-XVIII wieku. Uzbrojenie - broń - tapiserie. Malbork, 41-130.

Kębłowski J. 1967. Renesansowa rzeźba na Śląsku 1500-1560. Poznań.

Klapsia H. 1937. Harnischstudien II. Der prunkharnisch des Manierismus. "Jahrbuch der Kunsthistorischen Sammlungen in Wien" 11, 159-164.

Klapsia H., Thomas B. 1937. Harnischstudien I. Stilgeschichte des deutschen Harnisches von 1500 bis 1530. "Jahrbuch der Kunsthistorischen Sammlungen in Wien" 11, 139-158.

Kołosowski P. 2009. Dwór obronny w Chomętowie (gmina Dobiegniew, województwo lubuskie). Badania architektoniczno-archeologiczne. In: A. Janowski, K. Kowalski, S. Słowiński (eds.), XVI Sesja Pomorzoznawcza-Szczecin 22-24 listopada 2007 r. 2: Od późnego średniowiecza do czasów nowożytnych. Acta Archaeologica Pomoranica 3. Szczecin, 391-398.

König A., Rabe H., Westphal H. 1995. Renaissancezeitliche Waffenfunde und Ausrüstungzubehör aus den archäologischen Stadtkerngrabungen in Höxter. In: Schützengilde Höxter von 1595 e. V. (ed.), 400 Jahre Schützengilde Höxter 1595-1995. Höxter, 133-165.

Kowalski S. 2010. Zabytki architektury województwa lubuskiego. Zielona Góra.

Kovács T. S. 2016. Maces, War-hammers and Topors from Hungarian Collections. Budapest.

Krause S. 2017a. Wilhelm de Rogendorf and the Landsknechts. In: S. Krause (ed.), Fashion in Steel: The Landsknecht Armour of Wilhelm von Rogendorf. New Haven, London, 23-30.

Krause S. 2017b. Slashing in Renaissance Fashion. In: S. Krause (ed.), Fashion in Steel: The Landsknecht Armour of Wilhelm von Rogendorf. New Haven, London, 31-44.

Krause S. 2017c. Fashion in Steel. In: S. Krause (ed.), Fashion in Steel: The Landsknecht Armour of Wilhelm von Rogendorf. New Haven, London, 45-62.

Krenn P. 1997. Schwert und Spiess. Landeszeughaus in Graz. Ried im Innkreis.

Krenn P., Rebensteiner Ch. 1992. Checklist of the Exhibition. In: P. Krenn, W. J. Karcheski Jr., Imperial Austria: Treasures of Art, Arms \& Armour from the State of Styria. Houston, 103-129.

Kuczer J. 2007. Szlachta w życiu społeczno-gospodarczym księstwa glogowskiego w epoce habsburskiej (15261740). Zielona Góra.

Laking G. F. 1920. A Record of European Armour and Arms through Seven Centuries 3. London.

LaRocca D. J. 1991. Elements of a Light-Cavalry Armor. In: Recent Acquisitions: A Selection, 1990-1991. "The Metropolitan Museum of Art Bulletin" 49(2), New York, 23.

LaRocca D. J. 2004. Monsters, Heroes and Fools: a Survey of Embossed Armor in Germany and Austria, ca. 1475 ca. 1575. In: G. Groenendijk (ed.), A Farewell to Arms - Studies on the History of Arms and Armour. Liber Amicorum in honour of Jan Piet Puype, Former Senior Curator of the Army Museum Delft. New York, 35-55.

Lazar T. 2017. The Slovenian Lands as the Armed Frontier of the Holy Roman Empire. "Fasciculi Archaeologiae Historicae" 30, 59-72.

Lüken S. 2010. Kaiser Maximilian I. “der letzte Ritter”. In: R. Atzbach, S. Lüken, H. Ottomeyer (eds.), Burg und Herrschaft Eine Ausstellung des Deutschen Historischen Museums Berlin, 25. Juni bis 24. Oktober 2010. Dresden, 240-241.

Lüken S. 2019. Die Armbrust in Krieg und Frieden. In: S. Lüken. J. Sensfelder (eds.), Die Armbrust - Schrecken und Schönheit: Bestandskatalog des Deutschen Historischen Museums. Berlin, 31-41.

Łaszkiewicz T., Michalak A. 2007. Broń i oporzadzenie jeździeckie z badań i nadzorów archeologicznych na terenie Międzyrzecza. "Acta Militaria Mediaevalia” 3, 99-176. 
Mann J. G. 1929. Notes on the Armour of the Maximilian Period and the Italian Wars. "Archaeologia" 79, 217-244.

Mann J. G. 1962. Wallace Collection Catalogues. European Arms and Armour. Text with Historical Notes and Illustrations 1: Armour. London.

Marek L. 2008. Broń biała na Ślasku. XIV-XVI wiek. Wratislavia Antiqua 10. Wrocław.

Marek L. 2009. Boar- and Bear- Hunting in Post Medieval Silesia. Archaeological Evidence. "Fasciculi Archaeologiae Historicae" 23, 101-108.

Marek L. 2014. Europejski styl. Militaria z Elblaga i okolic. Studia Archeologiczne 47. Wrocław.

Marek L., Bis W. 2013. Elementy uzbrojenia ochronnego z królewskiego arsenatu w Tykocinie z drugiej połowy XVI-poczatku XVII w. "Kwartalnik Historii Kultury Materialnej” 61(4), 529-559.

Marek L., Mucha B. 2006. Kord z Henrykowa koło Szprotawy. "Acta Militaria Mediaevalia" 2, 217-222.

Michalak A. 2010. Wieża rycerska rodziny von Warnsdorf w Witkowie. "Z otchłani wieków" 65(1-4), 167-173.

Michalak A. 2012. Zbrojni mężowie z różnych epok. Nagrobki Baltazara von Kittlitz i Henryka von Zedlitz $z$ kościoła pw. Św. Marcina w Świdnicy - próba porównania uzbrojenia. In: J. Orlicka-Jasnoch (ed.), Świdnica-rycerskie gniazdo. Materiały z konferencji popularnonaukowej, Świdnica, 29 września 2012 r. Świdnica, 24-29.

Michalak A. 2019. Arma Confinii. Przemiany późnośredniowiecznej broni z rubieży Ślaska, Wielkopolski, Brandenburgii i Łużyc. Zielona Góra.

Michalak A., Wawrzyniak P. 2011. Nowożytny topór z Kożuchowa. "Archeologia Środkowego Nadodrza" 8, 155-168.

Mrozowski P. 1994. Polskie nagrobki gotyckie. Warszawa.

Müller H. 2002. Albrecht Dürer: Waffen und Rüstungen. Berlin.

Müller H., Kunter F. 1984. Europäische Helme: aus der Sammlung des Museums für Deutsche Geschichte. Berlin.

Niox G. 1917. Le Musée de L'Armée: Armes \& Armures anciennes et souvenirs historiques les plus précieux 1. Paris.

Norman A. V. B. 1974. Note on a Tower Armour Pedigree. "The Journal of the Arms and Armour Society" 8(1), 91-94.

Norman A. V. B. 1980. The Rapier and the Small-Sword 1460-1820. North Stratford.

Oakeshott R. E. 1980. European Weapons and Armour. Woodbridge.

Patała A. 2018. Pod znakiem Świętego Sebalda. Rola Norymbergii w ksztaltowaniu późnogotyckiego malarstwa tablicowego na Ślasku. Wrocław.

Patorski R. 2010. Polichromie w kościele pw. św. Jana Chrzciciela ufundowane przez starostę międzyrzeckiego Wawrzyńca myszkowskiego. In: B. Mykietow, M. Tureczek (eds.), Ziemia Międzyrzecka w przeszłości 8. Międzyrzecz, 43-51.

Pfaffenbichler M. 1989. Rüstungen all'Antika. In: Fürstenhöfe der Renaissance: Giulio Romano und die klassische Tradition: Kunsthistorisches Museum Wien, Neue Burg, 6.12.1989-18.2.1990. Wien, 236-247.

Puype J. P., Stevens H. 2010. Arms and Armour of Knights and Landsknechts in the Netherlands Army Museum. Delft.

Pyhrr S. W., Godoy J. A., Leydi S. 1998. Heroic Armor of the Italian Renaissance: Filippo Negroli and His Contemporaries. New York.

Quaas G. (ed.) 1992. Eisenkleider. Plattnerarbeiten aus drei Jahrhunderten aus der Sammlung des Deutschen Historischen Museums. Berlin.

Reißmann K. 1937. Die Kunstdenkmäler des Stadt- und Landkreises Landsberg (Warthe). Berlin.

Richardson T. 2009. Tonlet Armour. In: G. Rimer, T. Richardson, J. P. D. Cooper, Henry VIII. Arms and the Man. Leeds, 122-127.

Scalini M. 1996. The Armoury of the Castle of Churburg. Udine.

Sijarić M. 2014. Hladno oružje iż Bosne i Hercegovine u arheologiji razvijenog i kasnog srednjeg vijeka. Sarajevo. Springer C. 2010. Armour and Masculinity in the Italian Renaissance. Toronto.

Szczegóła H. 1968. Koniec panowania piastowskiego nad środkowa Odrą. Zielona Góra.

Thomas B. 1937. Harnischstudien I: Stilgeschichte des deutschen Harnisches von 1500 bis 1530. "Jahrbuch der Kunsthistorischen Sammlungen in Wien" 11, 139-158.

Thomas B. 1938. Harnischstudien III: Stilgeschichte des deutschen Harnisches von 1530 bis 1560. "Jahrbuch der Kunsthistorischen Sammlungen in Wien" 12, 175-202.

Thomas B., Gamber O. 1949. Konrad Seusenhofer - Studien zu seinen Spätwerken zwischen 1511-1517. "Konsthistorisk Tidskrift" 18, 37-70.

Thomas B., Gamber O. 1954. Die Innsbrucker Plattnerkunst. Austellungskatalog. Innsbruck. 
Thomas B., Gamber O. 1976. Katalog der Leibrüstkammer. I Teil. Der Zeitraum von 500 bis 1530. Kunsthistorisches Museum Wien - Waffensammlung. Wien.

Troso M. 1988. Le armi in asta delle fanterie Europee (1000-1500). Novara.

Tureczek M. 2009. Inskrypcje województwa lubuskiego. Powiat świebodziński. Corpus Inscriptionum Poloniae 10(4). Toruń.

Waldman J. 2005. Hafted Weapons in Medieval and Renaissance Europe. The Evolution of European Staff Weapons between 1200 and 1650. Leiden, Boston.

Wanke T. 2009. Anderhalbhänder - Zweihänder - Langes Schwert. Klassifikation, Nutzung und Bezeichnung der großen Schwerter des Spätmittelalters und der frühen Neuzeit. "Waffen- und Kostümkunde" 51(2), 113-208.

Wegeli R. 1929. Inventar der Waffensammlung des Bernischen Historischen Museums in Bern 2: Schwerter und Dolche. Bern.

Williams A. 2003. The Knight and the Blast Furnace. Leiden, Boston.

Witecki J. 2013. Uzbrojenie ochronne. In: J. Witecki, M. Świderska-Łupińska, Oręż europejski. Wrocław, 305-312.

Zdrenka J. 2015. Inskrypcje województwa lubuskiego. Miasto i powiat Gorzów Wielkopolski (do 1815 roku). Corpus Inscriptionum Poloniae 10(7). Torun.

Żygulski Z. Jr. 1975. Broń w dawnej Polsce na tle uzbrojenia Europy i Bliskiego Wschodu. Warszawa. 